\title{
CARACTERIZAÇÃO DA DINÂMICA HÍDRICA E DO MATERIAL PARTICULADO EM SUSPENSÃO NA BAÍA DE PARANAGUÁ E EM SUA BACIA DE DRENAGEM
}

\author{
ALESSANDRAMANTOVANELLI
}

\author{
DISSERTAÇÃO DE MESTRADO - Programa de Pós-Graduação em Geologia - UFPR \\ DATA DE DEFESA: 2 ago. 1999
}

A dinâmica hídrica e do material particulado em suspensão (MPS) e suas principais funções motrizes (maré e aporte de água doce) foram analisadas nas baías de Antonina e Paranaguá. Utilizaram-se dados de 8 monitoramentos efetuados numa seção transversal, durante ciclos semidiurnos de maré e de 20 perfis longitudinais de medição ao longo destas baías, realizados em diferentes estágios do ciclo maré (estofa, enchente, vazante). Estas medições incluem ciclos de sizígia e quadratura, em condições de reduzido (inverno) e elevado aporte de água doce (verão). Paralelamente, quantificaram-se o aporte de água doce e a carga MPS dos principais rios da bacia de drenagem deste sistema estuarino. Os aportes médios de água doce e MPS provenientes da drenagem continental foram cerca de 4 vezes superiores durante o verão, em função do maior excedente hídrico ( 3,5 vezes) e potencial de erosividade pela chuva ( 8 vezes), observados neste período em relação ao inverno. A maior parte da carga de MPS (50-80\%) foi introduzida no sistema em curtos períodos de tempo (5-11\%). A variação sazonal do aporte de água doce exerceu forte controle na salinidade média, no posicionamento do limite de intrusão de sal e na magnitude de estratificação vertical de salinidade ao longo das baías de Antonina e Paranaguá . Entretanto, o gradiente horizontal médio de salinidade foi próximo nos dois períodos (inverno e verão), sofrendo uma intensificação na baía de Antonina, sujeita a uma maior influência da descarga continental. As correntes, a estratificação de salinidade e as concentrações de MPS apresentaram uma acentuada variação entre os ciclos de sizígias e de quadraturas. O grau de mistura ou estratificação vertical foi primariamente governado pela intensidade das correntes de maré e, secundariamente, pelo aporte de água doce. A baía de Paranaguá (numa seção em frente a esta mesma cidade) foi classificada como um estuário parcialmente misturado, do tipo 2 , do diagrama estratificação-circulação, proposto por Hansen \& Rattray (1966). O aumento da estratificação vertical de salinidade, concomitante à redução da velocidade média das corren- tes, intensificou a circulação gravitacional, diminuindo a fração de sal transportada por difusão. Em condições extremas de alta estratificação do sistema, observadas particularmente nas quadraturas, o transporte de sal estuário acima ocorreu quase exclusivamente por advecção. Nos ciclos com reduzido aporte de água doce e com fontes correntes, predominaram os processos difusivos e a circulação residual orientou-se preponderantemente estuário acima ou abaixo. O efeito combinado das assimetrias nas velocidades médias de correntes e na duração entre os estágios de enchente e vazante explicou a magnitude e o sentido da circulação residual e do transporte de volume resultante do sistema. A dinâmica do MPS relacionou-se intrinsecamente aos processos cíclicos de erosão, ressuspensão e sedimentação condicionados pelas correntes de maré. A intensidade e estrutura vertical das correntes (gradiente de velocidade) exerceram influência no montante ressuspendido e, o grau de turbulência, na dispersão do MPS ao longo da coluna d'água. A ressuspensão foi mais pronunciada nas sizígias, sob fortes correntes, enquanto nas quadraturas houve o predomínio da advecção. Identificaram-se defasagens entre as máximas velocidades de corrente e as concentrações de MPS, sendo esta histerese mais pronunciada nas vazantes de sizígia. A zona de máxima turbidez (ZMT) situou-se entre os quilômetros 30 e 40 a montante da desembocadura da baía de Paranaguá nas enchentes e estofas da alta e, entre os quilômetros $16 \mathrm{e}$ 36 nas vazantes e estofas da baixa, particularmente nas regiões de afunilamento do canal estuarino, onde ocorre uma intensificação das correntes. Encontrou-se uma segunda região de altas concentrações de MPS na interface entre a água doce e a salgada, que pode estar associada ao processo de circulação gravitacional vertical. Embora a turbidez tenha sido elevada nesta região, as concentrações de MPS não se sobressaíram em relação aos outros locais da baía, sujeitos à forte ressuspensão. 